\title{
THE STRATEGY OF EMPOWERMENT BASED ON ESQ POWER: A SOCIAL INNOVATION IN THE POVERTY OVERCOMING
}

\author{
Peribadi \\ Department of Sociology Sciences, Faculty of Social and Political Science \\ Halu Oleo University, Southeast Sulawesi \\ Email: citaperibadi@gmail.com
}

\section{Abstract}

This research aimed to develop an innovation of empowerment strategy on ESQ Power-Based. It was designed through a phenomenology deductive, a case study and the methodof research and development or the procedure of member check. The three of them were used eclectically in order to design an ideal formulation. The research findings indicated that the actors and actresses of poverty overcoming in Kendari City have not had the emotional intelligence and spiritual intelligence yet as ESQ Power. As a result, they were not optimal in performing their duties, roles and responsibilities. Therefore, the urgency of empowerment paradigm on ESQ Power-Based that has been formulated and validated by the skillful validator must be used in the future to increase the sense of responsibility of the actor network in overcoming the pauperization and poverty.

Penelitian ini bertujuan untuk mengembangkan sebuah inovasi strategi pemberdayaan berbasis ESQ Power. Hal itu dirancang melalui deduksi fenomenologis, studi kasus serta metode penelitian dan pengembangan atau prosedur member check. Ketiganya digunakan secara eklektik untuk merancang formulasi ideal. Temuan penelitian menunjukkan bahwa aktor dan aktris penanggulangan kemiskinan di Kota Kendari belum memiliki kecerdasan emosional dan kecerdasan spiritual sebagai ESQ Power. Akibatnya, mereka tidak optimal dalam menjalankan tugas, peran dan tanggung jawabnya. Oleh karena itu, urgensi paradigma pemberdayaan berbasis ESQ Power yang telah dirumuskan dan divalidasi oleh validator ahli 
tersebut harus mulai digunakan ke depan untuk meningkatkan rasa tanggung jawab jaringan aktor dalam mengatasi pemiskinan dan kemiskinan.

Keywords: ESQ power; innovation empowerment; strategy

\section{Introduction}

A critical and skeptical analysis towards developmental paradigm with its various implications has taken place rapidly. However, all of them still show the unsatisfaction so that some discourses of the mind in which people emphasize more on the development of human's welfare and justice. It is no more avoidable that methodology of participatory training having orientation on dimension of social power, political power or bargaining position, and psychological power (Friedman, 1992; Chambers, 1996; Sugandhi, 2008; Glor, 2005; O'Connor, 2005; Bajraktari, 2015).

A variety of the empowerment programs have been developed in Kendari City Government, Southeast Sulawesi Province, but the empirical statistics showed that among ten areas and sixty four areas in Kendari, 25\% of them is classified as poor family (NPIUSE of Kendari City, 2014). On the other hand, conversely, The Government of Kendary City proved that the the rate of poverty has decreased until $6.4 \%$ since 2012 , the rate of the poverty has decreased until reached $6.4 \%$ (National Team of Poverty Overcoming Program (NTPOP)/TRPOC of Kendari City, 2015). The difference does not only confuse many parties but also become the indicator of the dysfunctional TRPOC as the coordinator of poverty overcoming in The Government of Kendari City.

The effort of studying the weakness and short coming of the empowerment program based on community, culture, and social capital, can be traced from various aspects and viewpoints. However, one thing that must be given priority is that the factor of minimization of ESQ Power as the social implication from the philosophy of positivism and post positivism that is value free (Agababahi \& Azadboni, 2015; Peribadi, 2015a). Possibly, the empowerment paradigm with locality initiative that so far has been implemented by Urban Poverty Overcoming Program (UPOP) and the side of NGO activists has almost been perfect. But, the network actors of poverty overcoming as the user of the above mentioned paradigm tends to be inconsistent and irresponsible in doing their duties and responsibilities In this context, the urgency on the study of reconstruction of the Empowerment Paradigm on ESQ Power - Based must 
be prioritized in the frame of Tertium Organum as intellectual paradigm Spirital - Based (Ouspensky, 2005; Peribadi, 2015c).

\section{Literature Review}

The explanations in this discussion are the key concepts employed as the base of interpretation towards the empowerment strategy on ESQ Power - Based. In this context, the discussion starts from the concepts of empowerment in the participatory perspective and is continued with the concepts of intelligence for the actor of development in overcoming the process of pauperization and its implication towards the poverty itself.

\section{Participatory Perspective}

According to Friedman (1992), the strategy of development that must be featured is the pressing on the process of the household empowerment and its members on dimension of social power, political power or bargaining position, and psychological power. Meanwhile, according to Sugandhi (2008), participatory approach as strategic method is an effort of enhancing the capability (capability building) and institutional strengthening of local community through the process of learning based on the experience in various aspects. The releasing moment from the imbalance situation must be done during the empowerment process. As supported by Chambers (1996), there needs to be a movement of the releasing from the susceptibility and powerlessness as the poverty rackets since it forces the poor family to sell their wealth even their valuable ones.

The method of participatory rural appraisal (PRA) as an integral part from participatory approach is highly required. However, in accordance with Suharto (2007) referring to Chambers (1985), apparently the above mentioned method is frequently faced to three things. First, personal bias is more dominant on men than on women and on the elites than on the poor. Second, the seasonal bias prefers travelling in cool and cold season to travelling in hot and rainy season that even has bad impact for the rural poor society. Eventually, diplomatic bias that does not expect to see the bad condition that can make them to be awakened (Alfitri, 2011; Mardikanto \& Soebiato, 2012; Peribadi, 2015b).

Application from this alternative approach is seen in the program of UPOP and NPIUSE emphasizing on the approach of participatory socio-cultural mapping and assessment that are also often called as participatory rural appraisal

el Harakah Jurnal Budaya Islam Vol. 19 No.2 Tahun 2017 
(PRA). This approach can also awake the attitude of government, stimulate discussion, and encourage the citizen to assemble, so that it re-strengthens the social relationship that has been faded for a long time. Accordingly, to reach the substantial target of three Powers (environmental, economic, and social infrastructures), NPIUSE has the guidance on the cycle of poverty overcoming starting from the phases of planning, implementation to evaluation as seen in Figure 1.

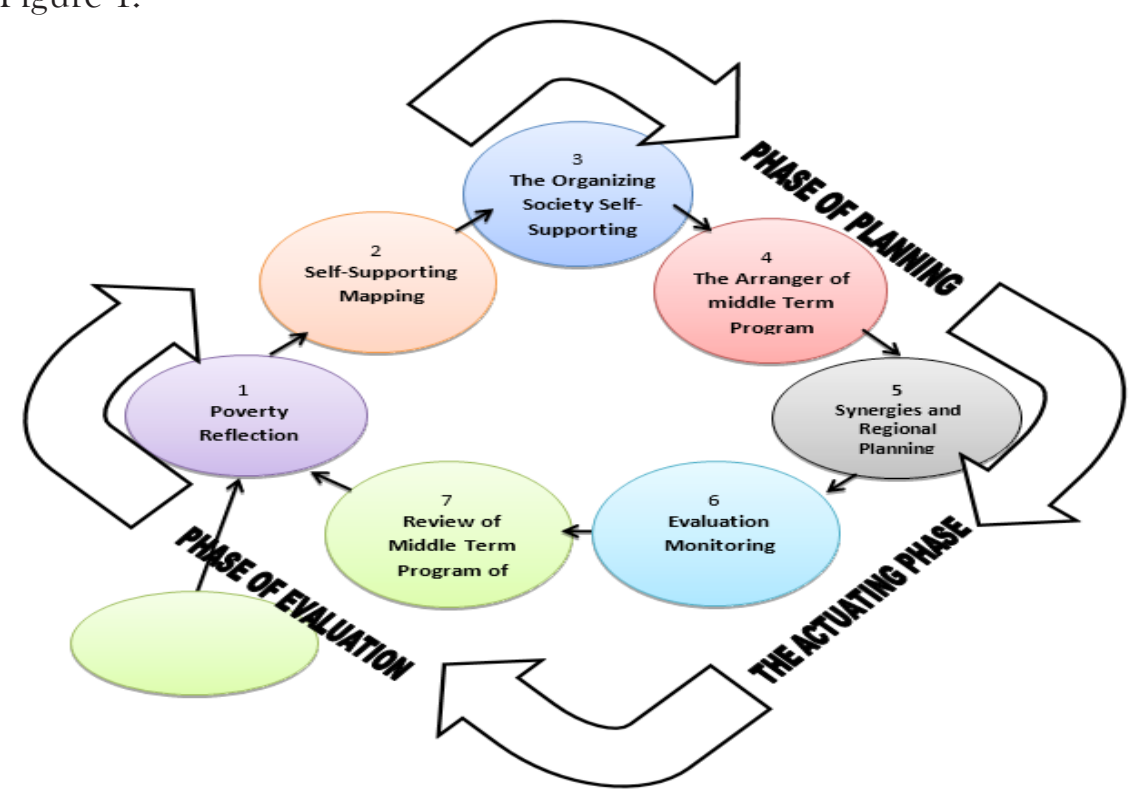

Figure 1. Cycle of Participatory Development that was elaborated from the Supplement of the General Guide for Implementing NPIUSE, 2011 and the Guide for Implementing NPIUSE, 2012

\section{Perspective of ESQ Power}

Weber (1930) argues that main source that presses on cultural values in developing modernization. According to him, religion has a lot of roles in forming capitalism because the social values coming from religion greatly influence the individual behavior (Budiman, 1995; Esfahani \& Seyedalighoreyshian, 2013). This theory is further popularly developed by the sociologist and anthropologist as Weberian.

According to Malik (2010), the epistemology of Weber and Khaldun has the substantivistic thought because both emphasize that religion has the encouraging power in forming economy. If Weber gives the example on 
the adherer of Calvinist Protestant that has stimulated the development of capitalism in Western world, Khaldun reflects the progressivity of economic development of Arabic nation in the beginning of Islam, even involves the close friends of Prophet Muhammad SAW as the economic actor. Thus, prophetic leadership has the base of its sociologic explanation of Weber's ethic impact on Protestant and Khaldun's work ethic on Arabic in the sake of other people's happiness and arouses a better substitute from himself (Khaldun, 2005, Malik, 2010; Utoyo, 2011; Rivai \& Arifin, 2013).

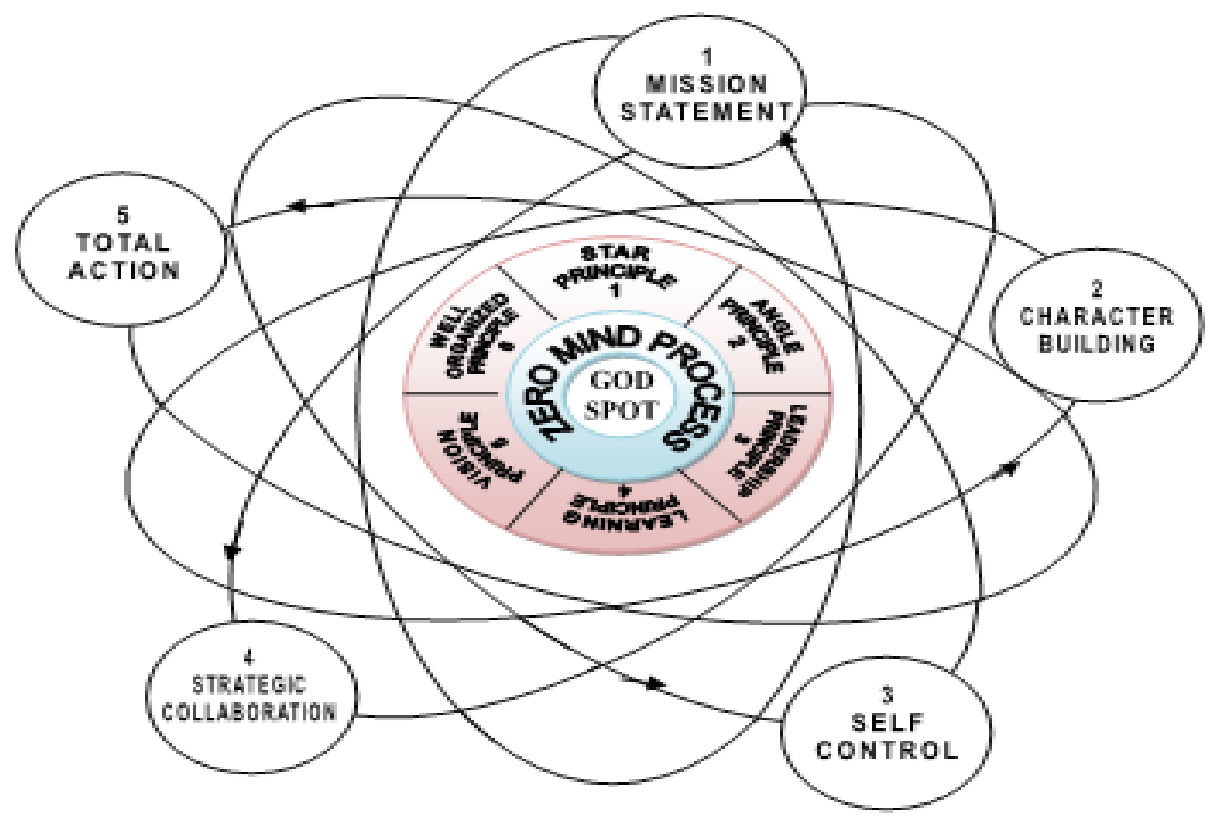

Figure 2. Cycle of Zero Mind Process from ESQ of Ary Ginanjar Agustian, 2000

Moreover, Agustian (2003) builds character and mentality of development through the training of ESQ Power by developing the concept of 165 as seen in Figure 2. Meanwhile, Santosa (2014) accelerates mental entrepreneurship through "Enter Trend Training" by developing the stories of trading of the Prophet Muhammad's close friend. Gardner quoted by Ula (2013) in theory of multiple intelligence states firmly that everybody has the capacity of nine kinds of intelligences. Hawari (2009) says the leaders must have good quality and fulfill the criteria of IQ (Intelligent Quotient), EQ (Emotional Quotient), CQ (Creativity Quotient) and SQ (Spiritual Quotient) or faith and piety. The effort of accelerating ESQ Power, Hidayatullah Pesantren (Islamic Boarding School) develops the spiritual journey of Pre Revelation 
and Revelation Scientification as seen in Figure 3 (Wibowo \& Herdimansyah, 2000; Suharsono, 2011).

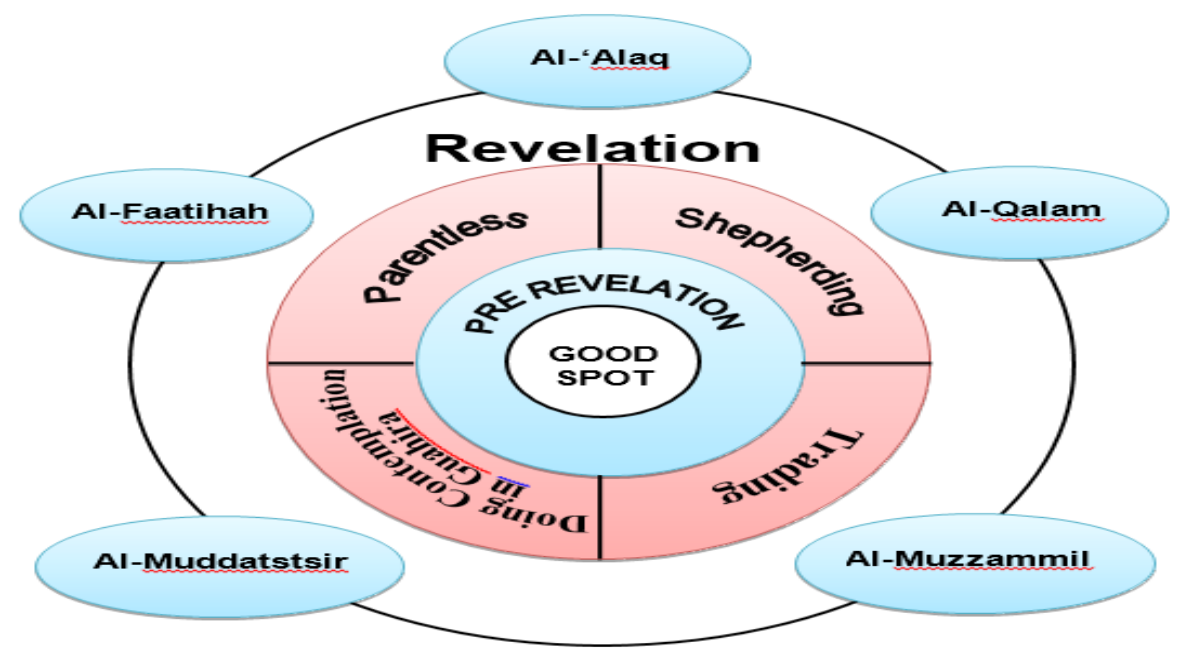

Figure 3. Cycle of PreProphetic and Prophetic Leadership that were elaborated from the Islamic Guidance of Leadership of Political Party at National Level of Hidayatullah, Jakarta (Peribadi, 2015b)

\section{Research Methods}

This research used constructivism paradigm and qualitative approach in the case of developing the metaphysical moral truth as the major premise through Popper's deductive phenomonology philosophy (Muhadjir, 2011). A case study was used to find out a variety of cases as the minor premis in the empowerment program. However, to avoid misconstruction of the analysis, Denzin's member check procedure (2009) and Altheide and Johnson's (2009) interpretive validity assessment were applied here.

The data were collected using participatory action research, in depth interview, and FGD, and documentary study. Phenomenological philosophy through interpretive data, interpretive analysis, and interpretive conclusion were use to analyze the data. In this context, the probabilistic theory was used as deductive proving and positioned to follow deductive logic of set theory (Muhadjir, 2011). Meanwhile, to the skillful validator was submitted an instrument of validation by the researcher when both meeting directly in several universities in Indonesia and communicating via email. 


\section{Results and Discussions}

The findings of the research showed the dysfunction of TRPOC in some ways. First was the integration on a variety of the poverty overcoming programs. Second was the inactiveness of Urban Learning Community (ULC) as the forum of conceptual study and degradation of societal institution and social organization of the farmer. Third was the disintegration of inter structural institution. Fourth, the miscommunication of network actor of poverty overcoming data collection controversy. Fifth was the spirit degradation of SelfSupporting Society Board (SSSB) and Self-Supporting Society Group (SSSG). Last was a declining stakeholder's voluntariness. In turn, the application of participatory cycle began to take place formalistically and was impressed to meet with the requirements only. In this context, urgency of empowerment formulation design on ESQ Power -Based are elaborated as follows.

\section{Formulation of Ideal Empowerment based on Pre Prophetic}

Social construction of "Pre Prophetic" of Muhammad described the spiritual journey that was preconditioned to be the leader of the future civilization. It could be seen from a situation in which he was an orphan, worked as a goat shepherder and a seller, then did the contemplation in Gua Hira. The portrait of Muhammad's life journey was a reflection of strong character-building as the effort of Zero Mind Process from all kinds of stupidity. Visually, it can be seen in Figure 4.



Figure 4. PreProphetic Construction and Its Effect towards Personal Strength and Partcipatory Cycle (Peribadi, 2015b) 
First, in the context of being an orphan, the Head of Humanity Division of Hidayatullah Islamic Boarding School argue that:

"When parents passed away, there is a learning process that can develop the spirit of independence. It bears the meaning that there is something (ilah) that can be relied on, except to the God. an arrogant santri (a name for the student in Islamic Boarding School) is assigned to clean lavatory everyday to keep away his arrogance. It highly urges to be reconstructed through a system of religious and humanistic and wise integral learning (Muhammad Junaid was interviewed by the researcher on February 20, 2015).

Second, in the context of goat shepherderer, a Professor of Animal Husbandry in Taddulako Palu niversity says that:

The shepherding status of Muhammad is internalized, it not only gives the contribution of nutritious meat of livestock animals to the society, but also as one gives the contribution of spirituality nutrition as stated in the Holy Qoran in An Nahl chapter 10, 68, and 69. In chapter 10: "He is the One having had given the rain water from the sky for you, some becomes the drinking water, some is used for fertilizing the plants, in which they are planted on, you shepherd your livestock". It becomes the source of thought to make the livestock animals fat (Kahar Kasim was interviewed by the researcher on February 17, 2015).

Thidty, trading as one of the important notes marking the process of journey of Muhammad as Rasul (the Messenger of the God) is not only a training of social and economic independence, but also a concretization of honesty. In this context, according to a Professor of Economy and ex-Rector of University of Islam Sultan Agung, Semarang:

The subject Prophetic Social Science (PSS) is given in this University by referring to the Holy Quran chapter 14: "And He is Allah who made ocean down for you in order that you can eat a fresh fish from it, and you take out the ornaments that you wear from the ocean; and you see the boat sailing on the ocean; and in order that you search the profit from His bestow, and in order you thank to God". (Masihu Kamaluddin was interviewed by the researcher on December 10, 2014).

In line with that statement, in the context of economy in Islam law, the Head of Economics Department and Director of International Program for Islamic Economics and Finance of Muhammadiyah University of Yogyakarta explains that:

"We must place Rasulullah (the Messenger of God) as the highest teacher in having science and knowledge. However, Syariah Bank, is one of the example how Muslim follow the way Muhammad traded with others and it has proven its greatness, so that now it competes with conventional banks. It means that the truth of Al Quran has been shown by the experts of Islam economy and conversely takes place in another discipline, as has ever been begun by Prof. Kuntowijoyo" (Masyhudi Muqorobin, interview on January 20, 2015). 
Fourth, contemplation in Guahira actually is the peak from an effort of Zero Mind Process to remove a variety of slavery manacles (ilah). Accordingly, the peak of supremacy from the Zero Mind Process is when a human declared Mission Statement by stating firmly that "there is no Ilah... (the epistemology) that deserves to be admired, except Him (epistemology for Human Sciences in Perspective of Prophetic). It was exactly meant by Fakih (2006) that the condition is not only a spiritual experience, but the theology of releasing that can be categorized as the theory of social change and critical theory.

The social change is closely related to social faith that has internalized in someone's brain as it is indicated in the Faithful Principle, they are: Angle Principle, Leadership Principle, Learning Principle, Vision Principle, and Well-Organized Principle. Eventually, to build a personal strength, it is not only needed the wanted feeling of affiliation, power and achievement, but also the ambition to reach achievements. Visually, it could be seen in Figure 5.

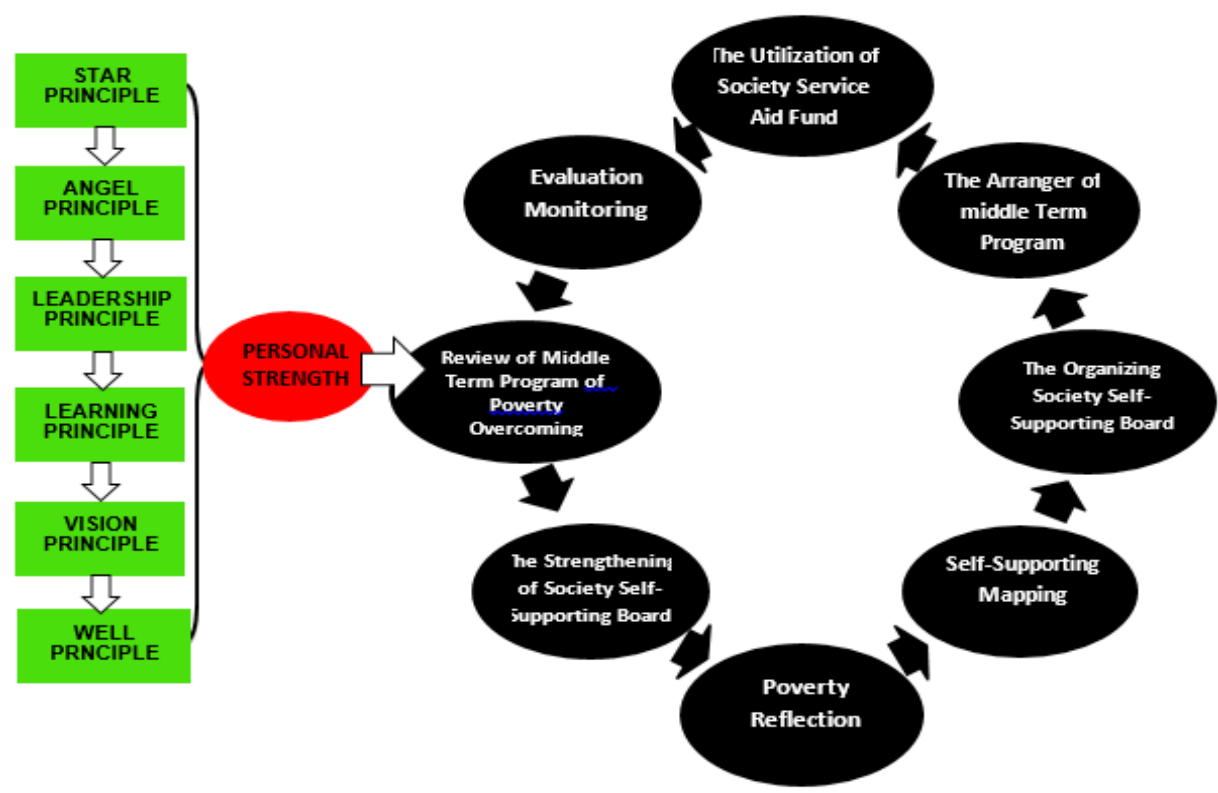

Figure 5. Prophetic Construction and its Effect towards Personal Strength and Participatory Cycle (Peribadi, 2015b) 


\section{Formulation of Ideal Empowerment based on Prophetic Scientification}

Prophetic social construction is described clearly in the Holy Quran. It is started from the Al Alaq and Al Qalam which describe a scientification strategy. Then, in AlMuzammil, it is about methodology of spiritual faculty developing methodology. After that, Al Mudatsir shows the description where God send the Messenger to enlight the darknessin Arabic. Last, Al Fatihah is about a condition where intellectuality and spirituality conflicts were neded to build a civil society. Visually, it is seen in Figure 6.



Figure 6. Prophetic Construction, Personal and Social Strength and Participatory Cycle (Peribadi, 2015b)

An empirical reality showed that people from any educational background may still want socialstatus and social prestige. The principle of "Allah Is My Everything in Life" must be kept since the beginning. Praying and fasting are two rituals that could create a personal strength. Meanwhile, tithe and hajji are synergic collaboration strategies and would certainly arouse social strength. Doing these rituals would make people to have a high awareness level as well as the intelligence to keep the mandate and people's belief. Visually, it can be seen in Figure 7. 


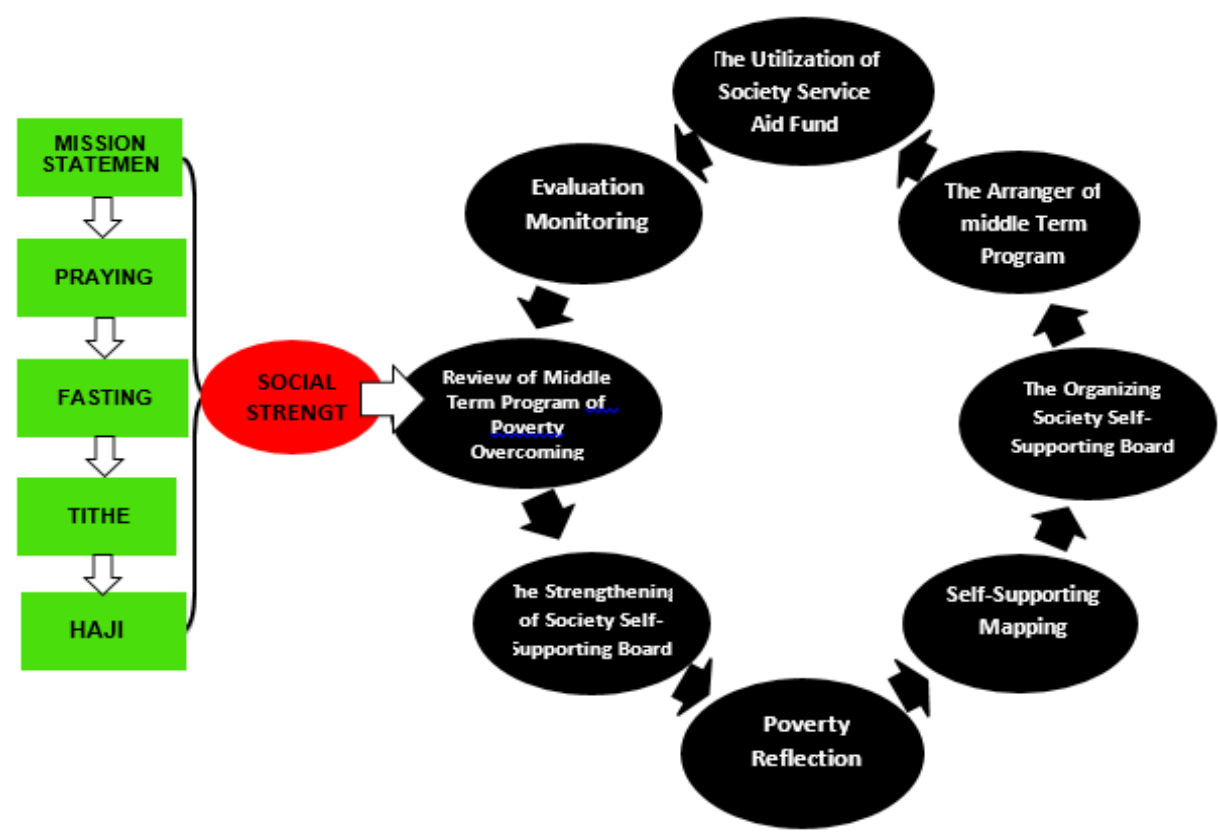

Figure 7. Prophetic Construction and Its Effect towards Social Strength and Participatory Cycle (Peribadi, 2015b)

Last, the positive result from a series of Prophetic paradigms is being Ikhsan the peak of a total action experience of someone in dedicating himself to Ilahi Rabbul Alamin (the God, the Creator of this universe world). When Ikhsan becomes the main motivation in developing a variety of horizontal and vertical activities people would not avoid doing other religious activities. Deep concentration in doing a ritual worship is a strategic step to be avoided from the susceptibility source called breaking points (critical point). Basically, the existence of the powerlessness, uncertainty, and scarcity will end with what is called by Weber as ambiguity, suffering, and ethical and social tenseness referring to the chaos society world (Kahmad, 2012).

\section{Conclusions}

First, from the perspective of structuration theory and some concepts of quotients, the process of legitimation indicates: (1) the lack of Intelligent Quotient due to the incapability factor of the actor and structure to finish the problems in each field; (2) the weakness of Emotional Quotient because of the inconsistent, unaccommodating, and in transparent factors; (3) the lowness of Creativity Quotient due to the incapability factor for changing threat into 
challenge then into an opportunity which has not been successful yet to generate the spirit and self-confidence; and (4) the lack of Spiritual Quotient because the networking actor has not completely kept the mandate strongly and inconsistently and has not been able to carry out the duty, role, and responsibility (Hawari, 2009).

Second the result of paradigmatic grand design contained in Figure 4 until Figure 7 is the synthetics of universal spirituality and Prophetic spiritual designed integrally and interdependently. The practice of contemplation in Guahira in the end of pre prophetic spiritual and determination of Mission Statement in the beginning of Prophetic Scientification in actuality is Zero Mind Process that can sharpen the reflection of thoughts. Likewise, personal strength can affect the mapping of self-supporting and social strength that are significant with the strengthening of institutional capacity. Meanwhile, the predicate of total action is human capital that has had capacity, capability, and integrity to build collaboration strategy in the case of arranging Middle Term Program of the Poverty Overcoming Program, of interlacing a synergistic relationship and of developing channeling program with a variety of institutions, especially with the side of bureaucracy.

Third it require an academic study on developing discourse of metaphysical realism methodology to support the study of deductive phenomenological interpretive that develops its syllogism structure from the variables of universal truth. Ontologically and epistemologically, this academic world only focuses on correspondence-realism, coherence realism, and pragmatism realism, so it is highly needed the development of metaphysical realism discourse.

Fourth, the strategy of empowerment in the future should start using Prophetic Development Paradigm as the result of reconstruction of empowerment strategy on ESQ Power - Based. that the writer has developed and written in this writing. As a matter of fact, in the participatory developmental paradigm based on the community that has so far been employed by UPOP and NPIUSE has been contained the universal spirituality In it in the perspective of Cultural Weberian. However, it increasingly becomes perfect when being integrated with Prophetic Spiritual and Prophetic Scientification in the perspective of Transcendental of Ibnu Khaldun. 


\section{References}

Agababahi, Hasan, Sayyed \& Azadboni, Mahdavi, Ramezan, 2015. Moral Realism As A Foundation For Education, International Journal of Technical Research and Applications (IJTRA) 29, 138-142.

Agustian, Ginanjar, Ary, 2003, Rahasia Sukses Membangkitkan ESQ Power, Sebuah Inner Journey Melalui Al-Ihsan, Jakarta: Arga.

Alfitri, 2011, Community Development: Teori dan Aplikasi. Yogyakarta: Pustaka Pelajar.

Altheide, L. David \& Johnson, M. John, 1994. Kriteria untuk Menilai Validitas Interpretif dalam Penelitian Kualitatif. In Denzim, Norman K. dan Lincoln, Yvonna S. (Eds.) Handbook of Qualitative Research, transl. Dariyatno et al., (2009) Yogyakarta: Pustaka Pelajar.

Bajraktari, I., Musa, 2015, The Feasibility of Corporate Social Responsibility and Social Welfare - The Case of Kosovo, Mediterranean Journal of Social Sciences 6(6), 187-193.

Borg. R. Walter and Gall, D. Meredith, 1989, Educational Research: An Introduction Fith Edition, New York: University of Oregon.

Budiman, Arief, 1995, Teori Pembangunan Dunia Ketiga, Jakarta: Gramedia.

Chamber, Robert, 1996, PRA Participatory Rural Appraisal - Memahami Desa Secara Partisipatif. Yogyakarta: Kanisius.

Denzin, Norman K. dan Lincoln, Yvonna S. (Eds.), 1994, Handbook of Qualitative Research, transl. Dariyatno et al., (2009), Yogyakarta: Pustaka Pelajar.

Esfahani, E., Nejatbakhsh, Ali and Seyedalighoreyshian, 2013. The Role of Spiritual Leadership in the Empowerment of Personnel, International Journal of Engineering Research and Applications (IJERA) 3(5), 1257-1274.

Fakih, Mansour, 2006, Runtuhnya Teori Pembangunan dan Globalisasi, Yogyakarta: Insist Press \& Pustaka Pelajar.

Friedman, J, 1992, Empowerment: The politics of alternative Development, NY: Blackwell Publishers.

Glor, D., Eleanor, 2005. About Empowerment, The Innovation Journal: The Public Sector Innovation Journal 10 (1), 1-12.

el Harakah Jurnal Budaya Islam Vol. 19 No.2 Tahun 2017 
Hawari, Dadang, 2009, IQ, EQ, CQ $\mathcal{E}$ SQ Kriteria Sumber Daya Manusia (Pemimpin) Berkualitas, Jakarta: Balai Penerbit FKUI.

Kahmad, Dadang, 2012, Sosiologi Agama. Bandung: PT. Remaja Rosdakarya. Khaldun, Ibnu, 2005, Muqoddimah Ibnu Khaldun, transl. Ahmadie Thoha, Jakarta: Pustaka Firdaus.

Kuntowijoyo, 2008, Paradigma Islam Interpretasi untuk Aksi. Bandung: Mizan Pustaka.

Malik, Luthfi, Muhammad, 2010, Etos Kerja, Pasar dan Masjid: Studi Sosiologi Mobilitas Perdagangan Orang Gu-Lakudo di Sulawesi Tenggara, Disertasi, FISIP, Program Studi Sosiologi, Jakarta: UI Depok.

Mardikanto, Totok dan Soebiato, Poerwoko, 2012. Pemberdayaan Masyarakat: dalam Perspektif Kebijakan Publik. Bandung: Alfabeta.

Monif, Abuya dan Kamaluddin, Masihu, 2014, Rasulullah's Business School. Semarang: Tim Dakwah Abuya, Banarang Gunungpari.

Muhadjir, Noeng, 2011, Metodologi Penelitian, Paradigma Positivisme Objektif, Fhenomenologi Interpretatif Logika Bahasa Platonis, Chomskyist, Hegelian dan Hermeneutik, Paradigma Studi Islam, Matematik Recursion-Set Theory \& Struktural Equation Modeling dan Mixed, Rake Sarasin, $4^{\text {th }}$ edition, Yogyakarta: Lembaga Pengembangan Informasi Da’wah Islam

NPIUSE, 2014. Report of Activity Progress of NPIUSE of Kendari City, August in 2014.

NPIUSE, 2014. Report of Activity Progress of NPIUSE of Kendari City, December in 2014.

NTPOP/TRPOC of Kendari City in 2015.

O'Connor, Denise, 2005, Participatory Processes: Creating a "Marketplace of Ideas" with Open Space Technology, The Innovation Journal: The Public Sector Innovation Journal, 10 (1), 1-15.

Ouspensky, P.D. 2005, Tertium Organum, Paradigma Intelektual Berbasis Spritual, diterjemahkan oleh M. Khoirul Anam dan disunting oleh Suharsono, Inisiasi Press, Depok-Jakarta. 
Peribadi, 2015a. Strategy of Community Development Based on Prophetic Spirituality Academic Research International, SAVAP International, Vol. 6 (3) May 2015.

Peribadi, 2015b. Reconstruction of Participatory Paradigm Based on ESQ Power: A Strategy of Poverty Overcoming in Kendari City, South East Sulawesi, Lambert Academic Publishing (LAP), Germany.

Peribadi, 2015c. Discourse of Universum Organum Based on Revelation System, in Proceedings of the Second International Conference - Thoughts on Human Sciences in Islam (IC-THuSI), 18 - 19 November 2015, pp. 186-195.

Public Works Ministry, 2011. Suplement of General Guidance Implementation of NPIUSE. Jakarta: General Directorate of Cipta Karya.

Public Works Ministry, 2012. The Guidance of Implementation of NPIUSE in building Independence Collectively. Jakarta: General Directorate of Cipta Karya.

Rivai, Veithzal, Arifin, Arviyan, 2013, Islamic Leadership: Membangun Super leadership Melalui Kecerdasan Spiritual. Jakarta: Bumi Aksara.

Santosa, Ippho, 2014, Percepatan Rezeki Dalam 40 Hari Dengan Otak Kanan. Jakarta: Gramedia.

Sugandhi, Ayi, 2008, Pedoman Teknis Perencanaan Partisipatif PJM Pronangkis, PMU/Proyek,P2KP.www.p2kp.org/pustaka/files/modul_pelatihan08/ D/1/e/Modul-Pembangunan-Partisipatif.pdf).

Suharsono, 2011, Membangun Peradaban Islam: Menata Indonesia Masa Depan Dengan Al-Qur'an. Jakarta: Inisiasi Hidayatullah.

Suharto, Edi, 2007, Pekerjaan Sosial di Dunia Industri: Memperkuat Tanggung Jawab Sosial Perusahaan (Corporate Social Responsibility) (edisi ke-2), Bandung: Alfabeta.

Syaria'ti, Ali, 1985, Peranan Cendikiawan Muslim, Mencari Masa Depan Kemanusiaan Sebuah Wawasan Sosiologis, Salahuddin Press, Yogyakarta: Lembaga Pengembangan Informasi Da'wah Islam.

Tasmara, Toto, 2006, Spiritual Centered Leadership, Kepemimpinan Berbasis Spiritual, Gema Insani, Jakarta.

el Harakah Jurnal Budaya Islam Vol. 19 No.2 Tahun 2017 
Ula, Shoimatul. S., 2013, Revolusi Belajar: Optimalisasi Kecerdasan Melalui Pembelajaran Berbasis Kecerdasan Majemuk, Ar-Ruzz Media, Yogyakarta.

Utoyo, Indra, 2011, Manajemen Alhamdulillah, Melejitkan Kepemimpinan Diri dengan Teori Quranik. Bandung: Mizania.

Weber, Max, 1930, The Protestant Ethic and the Spirit of Capitalism, NY: The Guernsey Press.

Wibowo dan Herdimansyah (Editor), 2000, Panduan Ber-Islam, Paket Ma'rifat, Buku 1-5, Jakarta: Departemen Dakwah dan Penyiaran, Hidayatullah.

Yin, Robert K., 2008, Studi Kasus: Desain dan Metode. Jakarta: PT. Raja Grafindo Persada. 